\title{
Induced Reproduction and Reproductive Characteristics of Rhinelepis aspera Agassiz, 1829 (Osteichthyes: Siluriformes, Loricariidae)
}

\author{
Yoshimi Sato $^{1}$, Nelsy Fenerich-Verani ${ }^{2}$, José Roberto Verani ${ }^{2}$, Hugo Pereira Godinho ${ }^{* 3}$, \\ Edson Vieira Sampaio ${ }^{1}$ \\ ${ }^{1}$ Três Marias Hydrobiology and Hatchery Station/CODEVASF, P.O. Box 11, 39205-000 Três Marias, MG, Brazil ${ }^{2}$ \\ Department of Hydrobiology, Federal University of São Carlos, P.O Box 676, 13565-905 São Carlos, SP, Brazil; ${ }^{3}$ \\ Institute of Biological Sciences, Federal University of Minas Gerais, P.O.Box 486, 30161-970 Belo Horizonte, MG, \\ Brazil
}

\begin{abstract}
Rhinelepis aspera is the largest Loricariidae species found in the São Francisco river basin where it is now rarely caught. Brooders kept in tanks were hypophysed with crude carp pituitary extract (CCPE). Approximately $82 \%$ of the females responded positive to the treatment. The egg was opaque, demersal, round, yellow and adhesive. Egg stripping was done at 212 hour-degrees $(=8.2 \mathrm{~h})$ after application of the second dose of CCPE (water temperature $=25-26^{\circ} \mathrm{C}$ ). Hatching of the larvae occurred at 1022 hourdegrees $\left(=42.2 \mathrm{~h}\right.$ ), after fertilization of the eggs (water temperature $=24-25^{\circ} \mathrm{C}$ ). Fertilization rate of the eggs was $72 \%$. Absolute fecundity $(A F)$, initial fertility $(I F)$ and final fertility $(F F)$ in relation to the females' body weight are expressed, respectively, by the equations: $A F=-33993+122308 \mathrm{Wt}\left(r^{2}=\right.$ $0.88), I F=-14823+58619 W t\left(r^{2}=0.71\right)$ and $F F=-6553+29741\left(r^{2}=0.61\right)$
\end{abstract}

Key words: Hypophysation, Rhinelepis aspera, Siluriformes, São Francisco River

\section{INTRODUCTION}

The black armored catfish Rhinelepsis aspera Agassiz, 1829 ('cascudo-preto') is an important and currently rare commercial fish of the São Francisco River, although still found in large numbers in its main tributary, the Paracatu River. Its flesh is firm, tasty and practically devoid of bones and fat. It is caught with gill nets. Among the Loricariidae of the São Francisco river basin, $R$. aspera is the one that reaches the largest size, and can exceed $4 \mathrm{~kg}$ of body weight. $R$. aspera can be found throughout the basin of the São Francisco and Paraná rivers, with its typical location in the São Francisco river (Fowler, 1954).

There are few references on induced reproduction of Loricariidae: Plecostomus (=
Hypostomus) plecostomus found in the rivers of northeastern Brazil (Azevedo, 1938) and Rhinelepis aspera, from the Paraná river basin (Maranhão et al., 1988).

This work presents the results obtained from hypophysation of the $R$. aspera at Três Marias Hydrobiological and Hatchery Station, CODEVASF, at Três Marias, MG, Brazil. Preliminary results on induced spawning of this species were presented earlier (Sato et al., 1988).

\section{MATERIALS AND METHODS}

Fourteen Rhinelepis aspera males and 17 females were used in this study during the reproductive seasons of 1995-1996 and 19961997. They were caught in the Paracatu river and

* Author for correspondence 
kept in a $200 \mathrm{~m}^{2}$ pond with average depth of $1 \mathrm{~m}$ at Três Marias Hydrobiological and Hatchery Station of CODEVASF at Três Marias, State of Minas Gerais. Broodstock density was maintained at $1 \mathrm{~kg}$ of fish $/ 8 \mathrm{~m}^{2}$ of pond.

The method employed to induce spawning was hypophysation (Ihering et al., 1935; Ihering, 1937), using crude common carp pituitary extract (CCPE). Injections of CCPE (one for males and 2 for females), the interval between injections, the moment of egg stripping (in hourdegrees) and the rate of fertilization (estimated after closing of the blastopore) followed the methods described in WOYNAROVICH \& HORVÁTH (1980). The injections were applied intramuscularly close to the dorsal fin. Fertilization was performed 'dry' and the eggs were placed in 20-liter funnel type incubators.

Following data were recorded for the females: total length ( $\mathrm{Lt}, \mathrm{cm})$, body weight (Wt, g), Fulton's condition factor $\left(\mathrm{K}=\mathrm{Wt} .100 / \mathrm{Lt}^{3}\right)$, ova (stripped eggs) weight $(\mathrm{g})$, weight of the gonads ( $\mathrm{Wg}=$ weight of ova + weight of the gonads after stripping, in g), diameter of fresh, nonhydrated eggs and of hydrated eggs $(\mu \mathrm{m})$, diameter of the yolk sac at blastula stage $(\mu \mathrm{m})$, the perivitelline space $(\mu \mathrm{m})$, thickness of the chorion $(\mu \mathrm{m})$, fertilization rate (taken after blastopore closure, \%), gonadosomatic index $(\mathrm{GSI}=\mathrm{Wg} .100 / \mathrm{Wt}, \%)$, absolute fecundity (AF), initial (IF) and final fertility (number of stripped eggs and number of viable eggs after closing of the blastopore, respectively), and length of the newly hatched larvae $(\mu \mathrm{m})$. Relative fecundity, relative initial fertility, and relative final fertility were estimated in relation to female total length and body weight.

\section{RESULTS AND DISCUSSION}

The fishes were in condition to be hypophysed from November to February. Brood selection was based on the following characteristics: females with more protruding and reddish urogenital papilla; males releasing milky semen when abdominal pressure was applied.

The results obtained are summarized in Table I.
During the treatment, the females stayed practically immobile, showing no sign of ovulation moment. The same behavior was reported by Azevedo (1938) for P. plecostomus. Of the 17 treated females, $14 \quad(82,35 \%)$ responded releasing viable eggs.

Stripping was performed with difficulty due to their bodies being covered by bony plates. It occurred at $212 \pm 5$ hour-degrees $(=8.2 \mathrm{~h})$ after the application of the second dose of CCPE at water temperature of $25.8 \pm 0.4{ }^{\circ} \mathrm{C}$. The males released milky semen easily. Stripping of $R$. aspera from the Paraná river basin was performed at 280-340 hour-degrees, at water temperature of $22{ }^{\circ} \mathrm{C}$ (Maranhão et al., 1988).

$R$. aspera egg was opaque, adhesive, spherical, demersal, yellowish in color and apparently has a double membrane. After hydration, the eggs increased in volume by 1.34 times. $P$. plecostomus has also sticky and yellowish eggs, measuring $3.3 \mathrm{~mm}$ before hydration and become only slightly hydrated in contact with water (Azevedo, 1938). For P. commersonii (= Hypostomus commersonii), from the East basin in the State of Paraná, mature eggs were yellowish in color and had a diameter of $4.2 \mathrm{~mm}$ (fixed in formalin) (Agostinho et al., 1982). In Venezuela, the largest egg diameter recorded for Hypostomus argus was $3.25 \mathrm{~mm}$, while for Pterygoplichtys multiradiatus, the largest recorded diameter was $3.5 \mathrm{~mm}$ (Winemiller, 1989). Eggs of Hypostomus affinis and Hypostomus luetkeni of the Paraíba do Sul river basin, State of Rio de Janeiro were also yellow (Mazzoni, 1993). R. aspera eggs from the Paraná river basin had the diameter of $1.48 \mathrm{~mm}$, the yolk sac diameter of $1.25 \mathrm{~mm}$ and the perivitelline space of $0.11 \mathrm{~mm}$ (measurements taken from material fixed in formalin) (NupeliaFuem, 1996).

The GSI of hypophysed females was $13.72 \%$ (range $=10.5-17.98 \%$ ). Maximum GSI value of $17.56 \%$ was recorded for Plecostomus commersonii (Agostinho et al., 1982), 28.74\% for Hypostomus affinis (Mazzoni, 1993), 19.53\% for Hypostomus luetkeni (Mazzoni, 1993), $11.01 \%$ for Rhinelepis aspera, and $23.58 \%$ for Hypostomus sp (Vazzoler, 1996), the last two species from the Paraná River.

Absolute fecundity in $R$. aspera females ranging from 42.5 to $60.5 \mathrm{~cm}$ (Lt) was $149,486 \mathrm{eggs}$ (range $=81,900-347,604)$. For $R$. aspera of the Paranapanema River, Agostinho 
Table I. Reproductive characteristics of the black armored catfish Rhinelepis aspera, hypophysed at Três Marias Hydrobiological and Hatchery Station, during the reproductive seasons of 1995/96 and 1996/97.

\begin{tabular}{|c|c|c|c|c|}
\hline Parameter & $\mathrm{N}$ & Mean \pm SD & $\mathrm{CV}$ & Range \\
\hline \multicolumn{5}{|l|}{ MALES } \\
\hline Total length (Lt, cm) & 14 & $48.3 \pm 6.0$ & 12.5 & $40.5-59.0$ \\
\hline Body weight (Wt, g) & 14 & $1338 \pm 399$ & 30.0 & $768-2100$ \\
\hline Single dose of CCPE (mg $/ \mathrm{kg}$ of $\mathrm{Wt})$ & 14 & $2.6 \pm 0.2$ & 8.9 & $2.5-3.0$ \\
\hline \multicolumn{5}{|l|}{ FEMALES } \\
\hline Total length (Lt, cm) & 14 & $49.8 \pm 6.0$ & 12.1 & $42.5-60.5$ \\
\hline Body weight $(\mathrm{Wt}, \mathrm{g})$ & 14 & $1500 \pm 525$ & 35.0 & $890-2770$ \\
\hline Fulton's condition factor $(\mathrm{K})$ & 14 & $1,19 \pm 0,14$ & 11.89 & $1,00-1,46$ \\
\hline \multicolumn{5}{|l|}{ Doses of CCPE (mg / $\mathrm{kg}$ of $\mathrm{Wt}$ ) } \\
\hline first dose & 14 & $1.0 \pm 0.1$ & 8.9 & $0.8-1.0$ \\
\hline second dose & 14 & $5.8 \pm 0.4$ & 7.4 & $5.0-6.0$ \\
\hline Interval between doses $(\mathrm{h})$ & 14 & $14.3 \pm 0.4$ & 2.9 & $14.0-15.0$ \\
\hline Hour-degrees at stripping & 14 & $212 \pm 5$ & 2.0 & $205-220$ \\
\hline Water temperature at stripping $\left({ }^{\circ} \mathrm{C}\right)$ & 14 & $25.8 \pm 0.4$ & 1.7 & $25.0-26.0$ \\
\hline Gonadosomatic index (GSI, \%) & 14 & $13.72 \pm 2.13$ & 15.53 & $10.50-17.98$ \\
\hline Ova weight. $100 / \mathrm{Wt}(\%)$ & 14 & $6.77 \pm 1.65$ & 14.39 & $4.62-9.71$ \\
\hline Eggs/g of ova (n) & 14 & $718 \pm 31$ & 4.0 & $669-779$ \\
\hline \multicolumn{5}{|l|}{ Egg measurements $(\mu \mathrm{m})$} \\
\hline Non-hydrated egg diameter & $120 *$ & $1584.00 \pm 42.59$ & 2.69 & $1503.60-1653.96$ \\
\hline Hydrated egg diameter & $120 *$ & $1752.54 \pm 49.71$ & 2.84 & $1662.08-1843.87$ \\
\hline Yolk sac diameter & $120 *$ & $1286.38 \pm 39.83$ & 3.10 & $1220.59-1350.44$ \\
\hline Perivitelline space width & $120 *$ & $182.50 \pm 29.60$ & 1622 & $118.30-248.16$ \\
\hline Chorion thickness & $120 *$ & $50.58 \pm 6.61$ & 13.07 & $40.40-60.60$ \\
\hline Egg fertilization rate $(\%)$ & 14 & $72.4 \pm 8.8$ & 12.1 & $55.3-83.6$ \\
\hline Absolute fecundity (AF) & 14 & $149486 \pm 68547$ & 46.0 & $81900-347604$ \\
\hline Initial fertility (IF) & 14 & $73114 \pm 36530$ & 50.0 & $41899-183574$ \\
\hline Final fertility $(\mathrm{FF})$ & 14 & $51171 \pm 19949$ & 39.0 & $31550-107758$ \\
\hline $\begin{array}{l}\text { Relative fecundity ( } \mathrm{n} \text { of eggs } / \mathrm{kg} \text { of } \\
\text { female) }\end{array}$ & 14 & $98364 \pm 14991$ & 15.0 & $73783-125489$ \\
\hline $\begin{array}{l}\text { Relative IF ( } \mathrm{n} \text { of stripped eggs } / \mathrm{kg} \text { of } \\
\text { female) }\end{array}$ & 14 & $48560 \pm 11895$ & 24.0 & $31526-68837$ \\
\hline $\begin{array}{l}\text { Relative FF ( } \mathrm{n} \text { of viable eggs } / \mathrm{kg} \text { of } \\
\text { female) }\end{array}$ & 14 & $34932 \pm 9098$ & 26.0 & $25242-55918$ \\
\hline $\begin{array}{l}\text { Relative fecundity ( } \mathrm{n} \text { of eggs/cm of } \\
\text { female) }\end{array}$ & 14 & $2917 \pm 960$ & 33.0 & $1883-5746$ \\
\hline $\begin{array}{l}\text { Relative IF ( } \mathrm{n} \text { of stripped eggs/cm of } \\
\text { female) }\end{array}$ & 14 & $1429 \pm 533$ & 37.0 & $933-3034$ \\
\hline $\begin{array}{l}\text { Relative FF ( } \mathrm{n} \text { of viable eggs/cm of } \\
\text { female) }\end{array}$ & 14 & $1012 \pm 294$ & 29.0 & $725-1781$ \\
\hline Hour-degrees to hatching & 14 & $1022 \pm 31$ & 3.0 & $980-1070$ \\
\hline Water temperature to hatching $\left({ }^{\circ} \mathrm{C}\right)$ & 14 & $24.2 \pm 0.4$ & 1.8 & $24.0-25.0$ \\
\hline Lt of hatched larvae $(\mu \mathrm{m})$ & $120 *$ & $4175.75 \pm 104.48$ & 2.5 & $3999.88-4368.29$ \\
\hline
\end{tabular}

$\mathrm{N}=$ number of observations; $\mathrm{CCPE}=$ crude carp pituitary extract; $\mathrm{SD}=$ standard deviation; $\mathrm{CV}=$ coefficient of variation; $*=$ measurements taken from 6 females (20 eggs or 20 larvae/female). 


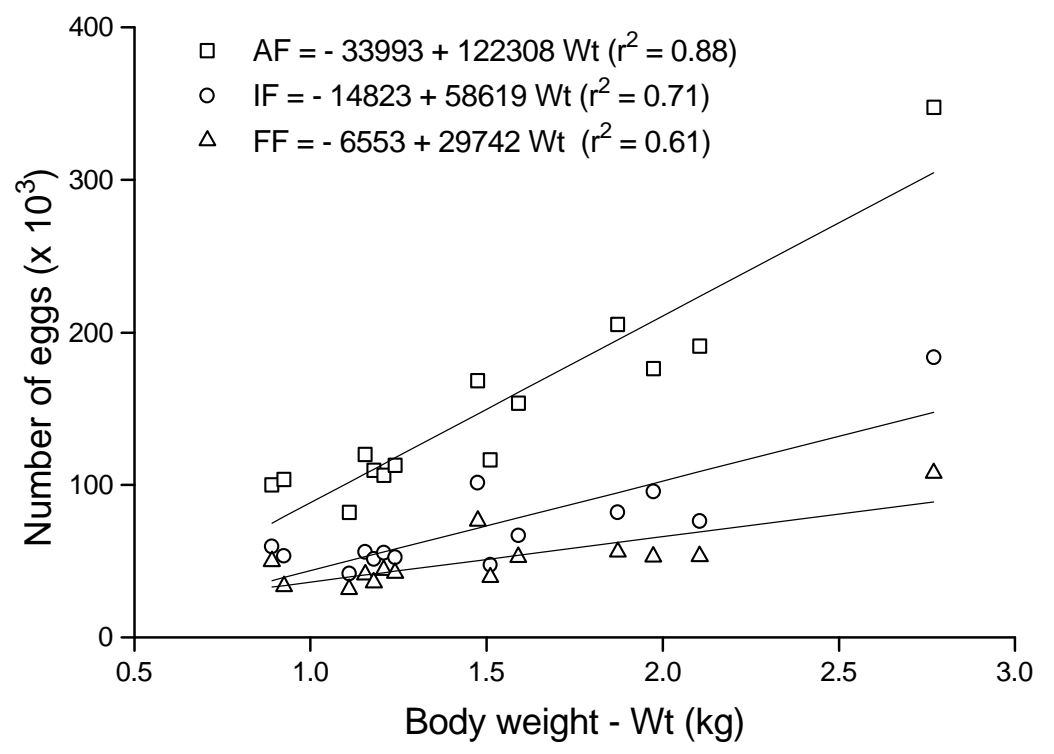

Figure 1. Linear relations of absolute fecundity (AF), initial fertility (IF), and final fertility (FF) on body weight (Wt), taken from 14 Rhinelepis aspera females hypophysed at Três Marias Hydrobiological and Hatchery, during the reproductive seasons of 1995/96 and 1996/97.

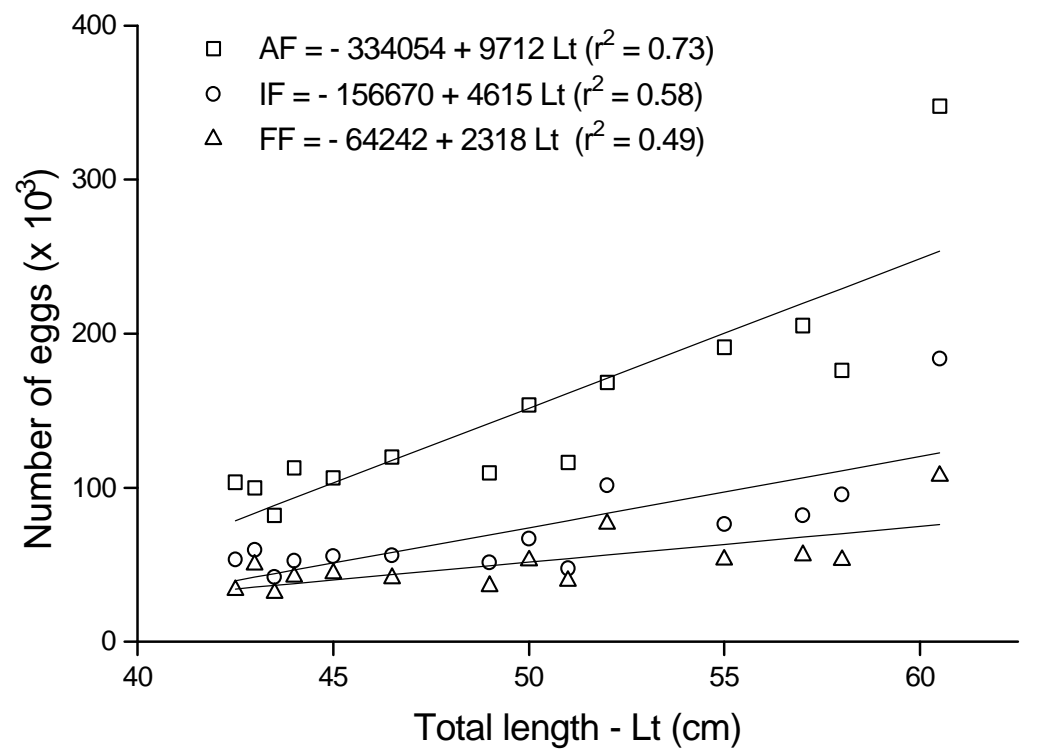

Figure 2. Linear relations of absolute fecundity (AF), initial fertility (IF), and final fertility (FF) on total length (Lt), taken from 14 Rhinelepis aspera females hypophysed at Três Marias Hydrobiological and Hatchery Station, during the reproductive seasons of 1995/96 and 1996/97. 
(1985) estimated the absolute fecundity as 43,380 eggs $($ range $=10,800-181,200)$ for females of $28.3 \mathrm{~cm}$ to $48.4 \mathrm{~cm} \mathrm{Lt}$ and Winemiller (1989), as 289 eggs $(\mathrm{Lt}=6.0 \mathrm{~cm})$ in Hypostomus argus and 763 eggs $(\mathrm{Lt}=23.3 \mathrm{~cm})$ in Pterygoplichtys multiradiatus. Hypostomus affinis had absolute fecundity of 1295-2310 eggs while the absolute fecundity in Hypostomus luetkeni was 367-936 oocytes (Mazzoni, 1993). The relation between absolute fecundity, initial fertility and final fertility and Wt and Lt are indicated in Figures 1 and 2. These values increased proportionally to $\mathrm{Wt}$ and $\mathrm{Lt}$.

Hatching of $R$. aspera larvae occurred at $1022 \pm$ 31 hour-degrees $(=42.2 \mathrm{~h})$ after fertilization of the eggs at water temperature of $24.2 \pm 0.4{ }^{0} \mathrm{C}$. For $R$. aspera of the Paraná River, Maranhão et al. (1988) recorded larvae hatching after 24 hours, and Azevedo (1938) described the $P$. plecostomus egg hatching at 7 or 8 days after fertilization. The larvae presented a sucker-type structure around the mouth that stuck to substrates or to the superficial water layer. The newly-hatched larvae measured 4,176 $\mu \mathrm{m} \mathrm{Lt}$ and lost their vitelline sac 84-96 h after hatching. $R$. aspera larvae from the Paraná river basin lost their vitelline sac $48 \mathrm{~h}$ after hatching (Maranhão et al., 1988). The larval Lt was $3.56 \mathrm{~mm}$ (Nupelia-Fuem, 1996) in formalin-fixed material. Vertical movements in the water column by the larvae were not observed in the present work.

Observations on brood mortality due to hypophysation was not carried out in the present paper. Sato et al. (1988) had already indicated that the species was highly resistant to the treatment.

\section{ACKNOWLEGMENTS}

The authors thank the Três Marias Hydrobiological and Hatchery Station (CEMIG/CODEVASF Agreement) for the use of its facilities and help during the work.

\section{RESUMO}

Rhinelepis aspera é a espécie que atinge maior porte dentre os Locariidae da bacia do rio São
Francisco onde é hoje raramente capturada. Reprodutores mantidos em viveiros foram hipofisados com extrato bruto de hipófise de carpa (EBHC). Aproximadamente $82 \%$ das fêmeas responderam positivamente ao tratamento. Seus ovos eram opacos, demersais, arredondados, amarelados e adesivos. A extrusão dos ovos foi feita a 212 horas-graus (= 8,2 h) após a aplicação da segunda dose de EBHC (temperatura da água $=25-26{ }^{\circ} \mathrm{C}$ ). A eclosão das larvas ocorreu a 1022 horas-graus (= 42,2 h) após a fertilização dos ovos (temperatura da água $=24-25{ }^{\circ} \mathrm{C}$ ). A taxa de fertilização dos ovos foi de $72 \%$. Fecundidade absoluta (AF), fertilidade inicial (IF) e fertilidade final (FF) em relação ao peso corporal das fêmeas foram expressa, respectivamente, pelas equações: $\mathrm{AF}=$ $-33993+122308 \mathrm{Wt}\left(\mathrm{r}^{2}=0,88\right), \mathrm{IF}=-14823$ $+58619 \mathrm{Wt}\left(\mathrm{r}^{2}=0,71\right)$ e $\mathrm{FF}=-6553+29741$ $\left(r^{2}=0.61\right)$.

\section{REFERENCES}

Agostinho, A.A. (1985), Estrutura da população, idade, crescimento e reprodução de Rhinelepis aspera (Agassiz, 1829) (Osteichthyes, Loricariidae) do rio Paranapanema, PR. Doctoral Thesis, Universidade Federal de São Carlos, São Carlos, Brazil

Agostinho, A.A., Narahara, M.Y. \& Godinho, H.M. (1982), Morfologia dos ovários de Plecostomus commersonni (Valenciennes, 1840) Osteichthyes - Loricariidae: desenvolvimento dos ovócitos e escala de maturidade. Rev. Brasil. Biol., 42 (1), 71-77

Azevedo, P. (1938), O cascudo dos açudes nordestinos "Plecostomus plecostomus". Arq. Inst. Biol., 9, 211-224

Fowler, H.W. (1954), Os peixes de água doce do Brasil. Arq. Zool. Estado São Paulo, 9, 1400 .

Ihering, R. von (1937), A method for inducing fish to spawn. Progr. Fish-Cult., 34, 15-16

Ihering, R. von, Azevedo, P., Pereira JR., C. \& Cardoso, D.M. (1935), Hypophysis and fish reproduction. Paper presented at $15^{\text {th }}$ International Physiological Congress, Leningrad/Moscow

Maranhão, T.C.F., Hickson, R.C. \& Severi, W. (1966), Desova induzida de cascudo preto 
Rhinelepis aspera (Osteichthyes, Loricariidae). Paper presented at $5^{\text {th }}$ Simpósio Brasileiro de Aqüicultura, Florianópolis, Santa Catarina

Mazzoni, R. (1993), Estratégia reprodutiva de duas espécies de Hypostomus Lacépède, 1803 (Osteichthyes, Loricariidae) do trecho inferior do rio Paraíba do Sul, Rio de Janeiro. Master's Dissertation, Universidade Federal do Rio de Janeiro, Rio de Janeiro

Nupelia-Fuem. (1996), Manual de identificação de ovos e larvas de peixes brasileiros de água doce. Report published by NUPELIAFUEM, Maringá, Paraná

Sato, Y., Cardoso, E.L. \& Sallum, W.B. (1988), Reprodução induzida do cascudo-preto (Rhinelepis aspera) da bacia do São Francisco. Paper presented at $6^{\text {th }}$ Encontro Anual de Aqüicultura de Minas Gerais, Belo
Horizonte, Minas Gerais

Vazzoler, A.E.A. (1996), Biologia da reprodução de peixes teleósteos: teoria $e$ prática. EDUEM, Maringá, Paraná

Winemiller, K.O. (1989), Patterns of variation in life history among South American fishes in seasonal environments. Oecologia, 81, 225241

Woynarovich, E. \& Horváth, L. (1980), The artificial propagation of warm-water finfishes - a manual for extension. FAO Fish Tech. Pap., 201, 1-183

Received: April 08, 1998;

Revised: June 02, 1998; Accepted: November 04, 1998. 